\title{
Gene expression of TMEM178, which encodes a negative regulator of NFATc1, decreases with the progression of asthma severity
}

\author{
Naiya B. Patel ${ }^{1}$, Lorena A. Ostilla ${ }^{1}$, Lyda Cuervo-Pardo² ${ }^{2}$ Sergejs Berdnikovs ${ }^{1}$ and Sergio E. Chiarella ${ }^{1 *}$ (D)
}

\begin{abstract}
In two independent microarray studies involving primary airway epithelial cells, the relative gene expression of TMEM178 decreases with the progression of asthma severity. Our manuscript creates a paradigm for future studies dissecting the role of Tmem178 in the pathogenesis of severe asthma.
\end{abstract}

Keywords: Asthma, Airway epithelium, Inflammation, Microarray

To the Editor,

The transmembrane protein 178 (Tmem178) is a novel phospholipase C gamma-2 (PLCY2)-dependent negative regulator of the nuclear factor of activated T-cells, cytoplasmic 1 (NFAT1c). In a seminal paper [1], Decker et al. showed that the loss of Tmem178 resulted in enhanced receptor activator of NF-kB ligand (RANKL)-induced calcium $\left(\mathrm{Ca}^{2+}\right)$ oscillations which led to increased NFAT1c activation. Furthermore, the authors demonstrated that this Tmem178-regulated pathway is a clinically-relevant negative feedback loop that significantly impacts osteoclast differentiation and bone homeostasis.

In our field, there has been only one prior publication linking Tmem178 to asthma [2]. This study included individuals with asthma $(\mathrm{n}=34)$, allergic rhinitis $(\mathrm{n}=7)$, or no underlying airway disease $(n=9)$ who were experiencing an acute respiratory illness (ARI). Participants attended three clinic visits, on average 2 days (D2), 6 days (D6), and 89 days (baseline) after the onset of ARI symptoms. Clinical data and nasal mucosal samples were collected during each of these visits. High-quality

\footnotetext{
*Correspondence: sergio-chiarella@northwestern.edu

${ }^{1}$ Northwestern University Feinberg School of Medicine, 211 East Ontario

Street, Suite 1000, Chicago, IL 60611, USA

Full list of author information is available at the end of the article
}

RNA extracted from these samples was subsequently used for microarray experiments. The authors showed that changes in TMEM178 gene expression (D6 versus D2) were associated with lower airway obstruction only in the group of asthmatics that were having an ARIinduced asthma exacerbation. There was no such association in healthy controls, patients with allergic rhinitis, or in asthmatics that were not having an ARI-induced asthma exacerbation. In addition, this study showed that these changes occurred regardless of medication use. Put together, these findings suggest that Tmem 178 may play a role in the pathogenesis of ARI-induced asthma exacerbations.

Here, we performed a secondary analysis of two highquality, publicly available microarray datasets (National Center for Biotechnology Information's Gene Expression Omnibus database; accession numbers GSE43696 and GSE63142) involving bronchoscopically obtained epithelial brushings from healthy donors and asthmatics. In the first study by Voraphani et al. [3] (GSE43696), fresh bronchial epithelial cells were obtained from healthy controls $(n=20)$, moderate asthmatics $(n=50)$, and severe asthmatics $(n=38)$. In the second study by Modena et al. [4] (GSE63142), fresh bronchial epithelial cells were collected from healthy controls $(n=27)$, non-severe asthmatics $(n=73)$, and severe asthmatics $(n=56)$. 

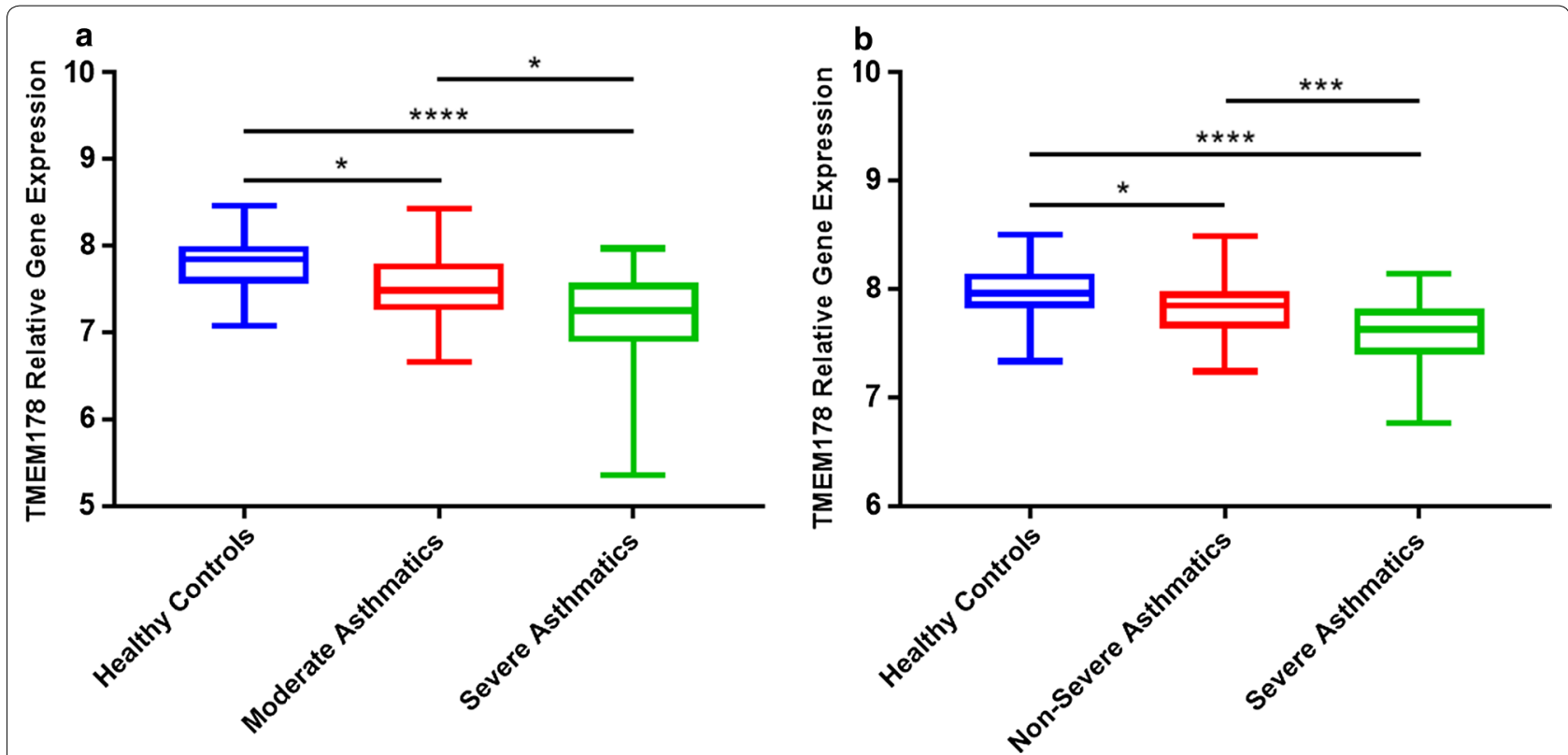

Fig. 1 Relative gene expression of TMEM178 is decreased in asthmatics when compared to healthy controls and this reduction progresses with asthma severity. a Data obtained from GSE43696. b Data obtained from GSE63142. ${ }^{* * *} p$-value $<0.0001 ;{ }^{* * *} p$-value $<0.001 ;{ }^{*} p$-value $<0.05$

For differential gene expression comparisons, we used moderated Benjamini-Hochberg t-tests with false discovery rate adjustments. Our results show that, in both cohorts, the relative gene expression of TMEM178 significantly decreases with the progression of asthma severity (Fig. 1a, b). Strikingly, when comparing TMEM178 levels in severe asthmatics to those of healthy controls, the difference is highly significant with an adjusted $p$ value of less than 0.0001 using Dunn's multiple comparison test. In the study providing data on the sexes of participants (GSE43696), there was no statistically significant sex difference in TMEM178 gene expression. In the light of these new findings, we postulate that Tmem178 may play a role in regulating NFAT-induced inflammation in severe forms of asthma, regardless of sex.

NFAT-induced inflammation is a recognized player in asthma pathogenesis. A recent study showed that activation of $\mathrm{Ca}^{2+} / \mathrm{NFAT}$ signaling events significantly contributed to the release of thymic stromal lymphopoietin (TSLP) from airway epithelial cells [5]. In addition, Jairaman et al. demonstrated that activation of the $\mathrm{Ca}^{2+}$ release-activated $\mathrm{Ca}^{2+}$ (CRAC) channel/NFAT pathway in airway epithelial cells led to the production of multiple inflammatory mediators, including TSLP, interleukin (IL)-6, and prostaglandin $E_{2}$ [6]. In a subsequent publication, this same group showed that the exposure of airway epithelial cells to house dust mite and cockroach allergen extracts led to the activation of protease-activated receptor type 2 (PAR2), opening of CRAC channels, and upregulation of downstream NFAT signaling pathways [7]. In turn, this led to the increased production of several inflammatory mediators, such as IL-6 and IL-8. Overall, these studies highlight the key role of the $\mathrm{Ca}^{2+}$ / NFAT pathway in the airway epithelial cell response to environmental stimuli relevant to asthma, including common allergens.

In conclusion, we have found that the relative gene expression of TMEM178 decreases as asthma severity progresses. Given the known function of Tmem178 as a negative regulator of NFAT, we speculate that Tmem178 plays an important role in NFAT-induced inflammation in patients with severe asthma. Further studies are required to determine the mechanisms by which Tmem178 controls NFAT transcriptional activity in asthma. This is particularly relevant given the recent successful clinical trial targeting the activity of GATA3 [8], another key transcription factor involved in the pathogenesis of asthma.

\section{Abbreviations \\ Tmem178: transmembrane protein 178; NFAT: nuclear factor of activated T-cells.}

\section{Acknowledgements \\ Not applicable.}

\section{Authors' contributions}

$N P, L O, L C, S B$, and SC analyzed the publicly available datasets. NB, SB, and SC wrote the manuscript. All authors read and approved the final manuscript. 


\section{Funding}

We used the following funding sources for analysis of the publicly available datasets:

The Northwestern University Allergy Immunology Research (NUAIR) Program T32 Grant.

The Ernest S. Bazley Grant to Northwestern Memorial Hospital and Northwestern University.

\section{Availability of data and materials}

The datasets analyzed during the current study are available in the National Center for Biotechnology Information's Gene Expression Omnibus database: Accession Numbers GSE43696 and GSE63142.

\section{Ethics approval and consent to participate}

Not applicable. This was a secondary analysis of publicly available microarray studies.

\section{Consent for publication}

Not applicable.

\section{Competing interests}

The authors declare that they have no competing interests.

\section{Author details}

${ }^{1}$ Northwestern University Feinberg School of Medicine, 211 East Ontario Street, Suite 1000, Chicago, IL 60611, USA. ${ }^{2}$ University of Florida, Gainesville, USA.

Received: 28 May 2019 Accepted: 29 July 2019

Published online: 08 August 2019

\section{References}

1. Decker CE, et al. Tmem178 acts in a novel negative feedback loop targeting NFATc1 to regulate bone mass. Proc Natl Acad Sci USA. 2015;112(51):15654-9.

2. McErlean $\mathrm{P}$, et al. Asthmatics with exacerbation during acute respiratory illness exhibit unique transcriptional signatures within the nasal mucosa. Genome Med. 2014;6(1):1.

3. Voraphani $\mathrm{N}$, et al. An airway epithelial iNOS-DUOX2-thyroid peroxidase metabolome drives Th1/Th2 nitrative stress in human severe asthma. Mucosal Immunol. 2014;7(5):1175-85.

4. Modena $\mathrm{BD}$, et al. Gene expression in relation to exhaled nitric oxide identifies novel asthma phenotypes with unique biomolecular pathways. Am J Respir Crit Care Med. 2014;190(12):1363-72.

5. Jia X, et al. Activation of TRPV1 mediates thymic stromal lymphopoietin release via the $\mathrm{Ca}^{2+} / \mathrm{NFAT}$ pathway in airway epithelial cells. FEBS Lett. 2014:588(17):3047-54.

6. Jairaman $\mathrm{A}$, et al. Store-operated $\mathrm{Ca}^{2+}$ release-activated $\mathrm{Ca}^{2+}$ channels regulate PAR2-activated $\mathrm{Ca}^{2+}$ signaling and cytokine production in airway epithelial cells. J Immunol. 2015;195(5):2122-33.

7. Jairaman A, et al. Allergens stimulate store-operated calcium entry and cytokine production in airway epithelial cells. Sci Rep. 2016;6:32311.

8. Krug N, et al. Allergen-induced asthmatic responses modified by a GATA3-specific DNAzyme. N Engl J Med. 2015;372(21):1987-95.

\section{Publisher's Note}

Springer Nature remains neutral with regard to jurisdictional claims in published maps and institutional affiliations.
Ready to submit your research? Choose BMC and benefit from

- fast, convenient online submission

- thorough peer review by experienced researchers in your field

- rapid publication on acceptance

- support for research data, including large and complex data types

- gold Open Access which fosters wider collaboration and increased citations

- maximum visibility for your research: over 100M website views per year

At BMC, research is always in progress.

Learn more biomedcentral.com/submissions 